Andrzej S. Turkanik

\title{
Of Kings and Reigns
}

A Study of Translation Technique in the Gamma/Gamma Section of 3 Reigns (1 Kings)

[Von Königen und Herrschaften. Eine Studie über die Übersetzungstechnik in der Gamma/Gamma-Sektion des 1. Buches der Königtümer (1. Könige).]

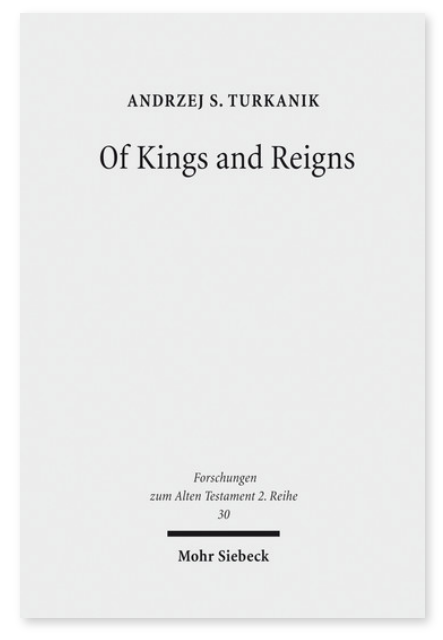

2008. XIV, 231 Seiten. FAT II 30

ISBN 978-3-16-151128-8

DOI 10.1628/978-3-16-151128-8

eBook PDF 89,00€

ISBN 978-3-16-149541-0

fadengeheftete Broschur 89,00€
Veröffentlicht auf Englisch.

Andrzeij Turkanik untersucht die Übersetzungstechnik in der Gamma/Gamma-Sektion (2.11-21.43) des 3. Buches der Königtümer (1. Könige) in der Septuaginta. Es gibt zahlreiche Unterschiede zwischen den wichtigsten Textzeugnissen, dem masoretischen Text und der altgriechischen Übersetzung. Andrzej S. Turkanik vergleicht die Texte in der griechischen und hebräischen Version, um deren Unterschiede zu bestimmen und einzuordnen, und um den Zustand des Materials zu bestimmen und die Arbeitsweise des Übersetzers aufzuzeigen. Des weiteren fragt er nach der Verläßlichkeit der Textversion in der Septuaginta, um den Originaltext in 1 Könige aufzudecken.

Andrzej S. Turkanik Born 1970; 2002 PhD at the Faculty of Oriental Studies, University of Cambridge; 2002-2005 lecturer in Old Testament at Schloss Mitersill Study Centre, Austria, since 2005 executive director there.

Jetzt bestellen:

https://mohrsiebeck.com/buch/of-kings-and-reigns-9783161511288?no cache=1

order@mohrsiebeck.com

Telefon: +49 (0)7071-923-17

Telefax: +49 (0)7071-51104 